\title{
Hubungan Empati dengan Agresivitas Siswa SMA Pertiwi 2 Padang Serta Implikasinya dalam Bimbingan dan Konseling
}

\author{
Siltami Elga Omala ${ }^{1}$, Firman $^{2}$, Taufik ${ }^{3}$ \\ ${ }^{123}$ Universitas Negeri Padang \\ *Corresponding author, e-mail: Siltamielgaomala@yahoo.com
}

\begin{abstract}
Abstrak
Penelitian ini dilatar belakangi oleh maraknya siswa yang melakukan agresivitas. Agresivitas merupakan perilaku negatif dan salah satu faktor yang diduga dapat meredamnya adalah empati. Penelitian ini bertujuan untuk: (1) mendeskripsikan tingkat agresivitas siswa, (2) mendeskripsikan tingkat empati siswa, dan (3) menguji signifikansi hubungan empati dengan agresivitas siswa. Penelitian ini merupakan penelitian jenis deskriptif korelasional dengan metode kuantitatif. Populasi penelitian ini adalah siswa SMA Pertiwi 2 Padang dan sampel sebanyak 152 siswa dipilih dengan Stratified Random Sampling. Data dianalisis dengan teknik statistik deskriptif dan teknik Pearson Product Moment. Temuan penelitian ini memperlihatkan bahwa: (1) tingkat agresivitas siswa berada pada kategori sedang, (2) tingkat empati berada pada kategori tinggi, dan (3) terdapat hubungan negatif yang signifikan antara empati dengan agresivitas dengan koefisien korelasi 0,695 dan taraf signifikansi 0,000 .
\end{abstract}

Keywords: Empati, Agresivitas.

How to Cite: Siltami Elga Omala, Firman, Taufik. 2018. Hubungan Empati dengan Agresivitas Siswa SMA Pertiwi 2 Padang serta Implikaisnya dalam Bimbingan dan Konseling. Konselor, VV (N): pp. XX-XX, DOI: 10.24036/XXXXXXXXXX-X-XX

This is an open access article distributed under the Creative Commons 4.0 Attribution License, which permits unrestricted use, distribution, and reproduction in any medium, provided the original work is properly cited. (O2017 by author and Universitas Negeri Padang.

\section{Pendahuluan}

Masa remaja merupakan periode yang akan dilalui dalam kehidupan manusia. Remaja adalah periode peralihan dari masa anak-anak menuju masa dewasa. Pada masa peralihan tersebut individu banyak mengalami tantangan dalam perkembangan baik dari dalam diri maupun dari luar diri terutama lingkungan sosial. Prayitno (2006:6) menjelaskan umur remaja berada pada rentang antara 13-21 tahun.

Pada periode peralihan remaja rentan terjadi perubahan dalam dirinya, salah satunya seperti ketidakseimbangan dan ketidakstabilan emosi, dalam arti emosi negatif lebih mudah muncul. Gangguan emosi ini lah yang dapat menjadi penyebab timbul tingkah laku negatif pada remaja. Sejalan dengan itu Santrock (2007: 20) menjelaskan bahwa pada masa remaja merupakan periode transisi perkembangan dari anak-anak menuju dewasa yang ditandai dengan perubahan pada aspek biologis, kognitif dan sosialemosional.

Idealnya remaja yang berkembang dengan baik tidak akan memperlihatkan perilaku negatif. Sejalan dengan itu Prayitno (2006: 8) mengatakan bahwa tingkah laku negatif bukan merupakan ciri perkembangan remaja yang normal, remaja yang berkembang dengan baik akan memperlihatkan tingkah laku yang positif. Pada kenyataannya, banyak remaja yang mengarah pada perilaku negatif. Salah satu perilaku negatif yang ditunjukkan remaja adalah perilaku agresif. Perilaku agresif adalah tingkah laku yang bertujuan menyakiti orang lain baik secara verbal maupun fisik, serta merusak harta benda milik orang lain.

Menurut Baron \& Byrne (2005) menyatakan agresi sebagai perilaku yang diarahkan dengan tujuan untuk menyakiti orang lain. Selain itu, David G, Myers (2012: 69) menyatakan perilaku agresif yaitu perilaku secara fisik atau verbal yang dimaksud untuk menyebabkan kerusakan. Hal yang sama juga dijelaskan oleh Atkinson, Atkinson, dan Hilgard (2008: 58) menjelaskan agresi adalah perilaku yang secara 
sengaja bermaksud melukai orang lain (secara fisik dan verbal dan menghancurkan harta benda). Selanjutnya, agresif merupakan ungkapan perasaan dengan kemarahan yang disertai emosi tinggi sebagai sarana untuk mencapai tujuan tertentu.

Menurut kamus besar bahasa Indonesia, agresivitas berasal dari kata agresif yang berarti bersifat atau tindakan, dapat didefinisikan menjadi suatu sifat yang cenderung memiliki keinginan untuk menyerang. Dapat disimpulkan agresivitas adalah perilaku seseorang yang menyebabkan luka fisik atau luka psikologis pada orang lain atau mengakibatkan kerusakan pada benda.

Hasil Penelitian Panavia (2012) menunjukkan bahwa siswa memiliki tingkat agresivitas yang tinggi. Penelitian Novia Nadia Bestari (2016) menunjukkan bahwa semakin tinggi dan positif interaksi sosial teman sebaya maka agresivitas siswa semakin rendah. Selanjutnya penelitian Randi Pratama (2015) perilaku agresif siswa berasal dari keluarga broken home secara umum berada pada kategori sedang. Penelitian yang dilakukan oleh Hafiz Hidayat (2013: 8) menunjukkan bahwa perilaku agresif siswa pada aspek menyakiti orang lain melalui verbal berada pada kategori tinggi. Berdasarkan penelitian Ismiati (2015) diketahui bahwa "perilaku agresif siswa berada pada kategori sedang".

Beberapa fenomena ditemukan di lapangan tentang perilaku agresif. Berdasarkan observasi pada tanggal 16 Januari 2018 di SMA Pertiwi 2 Padang ditemukan adanya anak-anak yang suka bertengkar, suka mengganggu teman dan suka mengolok-olok teman, memandang teman dengan lirikan sinis, adanya siswa yang menyakiti secara verbal, seperti membentak teman, siswa yang bertengkar dengan saling memanggil nama orangtua masing-masing, serta mengeluarkan kata-kata kotor.

Berdasarkan hasil wawancara pada tanggal 16 Januari 2018 di SMA Pertiwi 2 Padang dengan koordinator BK ditemukan siswa yang sering berkata kasar kepada teman sebaya, bertengkar dengan teman sebaya, senioritas, siswa mengejek teman yang keadaan fisiknya terganggu, menyebarkan kebohongan kepada teman, pembalasan marah kepada teman dengan cara mengucilkan dari kelompok bermain, siswa yang di sekolah merusak fasilitas sekolah seperti: mencoret-coret tembok, merusak meja dan kursi.

Berdasarkan hasil penelitian dan fenomen kenyataannya dilapangan masih banyak siswa yang berperilaku agresif. Hal ini berarti perkembangan kepribadian siswa tergolong kurang baik, remaja yang berkembang baik kepribadiannya, dapat menguasai keterampilan membina hubungan sosial dengan orang lain. Idealnya remaja dituntut untuk membina hubungan baru lebih matang dengan teman sebaya.

Sejalan dengan itu menurut Prayitno (2006: 43) Salah satu tugas perkembangan remaja yaitu kemampuan membina hubungan baru dan lebih matang dengan teman sebaya, membina hubungan baru tersebut salah satunya adalah empati. Remaja yang memiliki kemampuan empati mudah memahami perasaan teman sebaya, sehingga mereka cepat tanggap dan saling mereaksi secara positif perasaan temannya. Kohut (dalam Taufik , 2012: 40) melihat empati sebagai suatu proses di mana seseorang berfikir mengenai kondisi orang lain yang seakan-akan dia berada pada posisi orang lain itu.

Senada dengan hal diatas menurut Niu Jianghe (2009) salah satu faktor internal yang terkait dengan agresi adalah faktor emosi. Adapun pada faktor emosi terdapat beberapa aspek yaitu marah, iri/cemburu, dan empati. Namun marah, iri/cemburu berhubungan positif terhadap perilaku agresif, sedangkan empati berhubungan negatif terhadap tindakan agresif. Sejalan dengan itu sesuai dengan penelitian yang dilakukan oleh Paul A. Miller dan Nancy Eisenberg (1988) yang berjudul "The Relation of Empathy to Aggressive and Externalizing/Antisocial Behavior" dari hasil penelitian ini diperoleh kesimpulan bahwa empati memiliki hubungan negatif dengan agresi

Anak yang melakukan agresi merupakan anak yang memiliki empati pada orang lain yang tidak berkembang. Seperti yang dikemukakan oleh Koeswara. E (1988: 205), Kemampuan memberikan empati merupakan cara yang perlu diambil dalam usaha mencegah berkembangnya tingkah laku agresif. Kemampuan seperti itu dapat berkembang dengan baik bila individu dilatih dan melatih diri untuk mampu menempatkan diri pada dunia batin sesamanya, mampu merasakan dan yang dialami atau yang diinginkan sesamanya.

Guru BK mempunyai peran untuk membantu siswa dalam menangani tindakan agresifnya. Pelayanan bimbingan dan konseling merupakan bantuan yang diberikan kepada siswa untuk membantu memahami permasalahan yang dihadapinya agar terwujud kehidupan sehari-hari yang efektif. Guru bimbingan dan konseling sebagai pelaksana kegiatan pelayanan bimbingan dan konseling di sekolah dapat membantu siswa berkembang secara optimal sehingga tujuan pendidikan dapat tercapai. Dalam hal ini yang dituntut adalah pembentukan sikap dan perilaku siswa sesuai dengan nilai dan norma.

Dalam bimbingan dan konseling terdapat 4 bidang bimbingan yaitu sosial, pribadi, karir dan belajar. Empati dan agresivitas dalam BK berkaitan dengan bidang sosial dan pribadi. Guru BK disekolah dituntut agar dapat memberikan bantuan berupa pelayanan maupun pendekatan bimbingan dan konseling yang sesuai dan seoptimal mungkin kepada siswa. 
Bimbingan dan konseling memberikan layanan bantuan dibidang sosial dan pribadi. Bidang tersebut diimplementasikan dengan memberikan layanan informasi, layanan penguasaan konten, layanan konseling perorangan, layanan bimbingan kelompok dan konseling kelompok. Layanan-layanan tersebut bertujuan untuk membantu siswa meningkatkan kemampuan berempati sehingga remaja dapat membina hubungan baik dengan teman dan pengembangan keterampilan-keterampilan yang penting dalam kehidupan secara umum yang bisa mengurangi perilaku agresivitas siswa.

Berdasarkan fenomena yang telah dikemukakan, maka peneliti tertarik untuk mengkaji lebih mendalam mengenai "Hubungan Empati dan Agresivitas Siswa SMA Pertiwi 2 Padang serta Implikasinya dalam Bimbingan dan Konseling"

\section{Metodologi}

Penelitian ini merupakan penelitian jenis deskriptif korelasional dengan metode kuantitatif yang bertujuan untuk mendeskripsikan empati (X) dan agresivitas (Y). Populasi penelitian ini seluruh siswa SMA Pertiwi 2 Padang yang berjumlah 245 orang dengan sampel sebanyak 152 siswa yang dipilih dengan Stratified Random Sampling. Instrumen yang digunakan adalah kuesioner empati dan agresivitas yang. Data yang dikumpulkam dianalisis menggunakan statistik deskriptif dan teknik Pearson Product Moment dengan bantuan program SPSS for windows 20.

\section{Hasil Penelitian}

\section{Agresivitas SMA Pertiwi 2 Padang}

Temuan penelitian agresivitas dapat dilihat gambarnya sebagai berikut.

Tabel 1. Deskripsi Rata-rata (Mean), Standar Deviasi (SD), Skor Tertinggi (ST), Skor terendah (SR), dan Persentase (\%) Agresivitas (n=152)

\begin{tabular}{|c|c|c|c|c|c|c|c|c|c|c|c|c|}
\hline \multirow[b]{2}{*}{ No } & \multirow[b]{2}{*}{ Aspek } & \multirow[b]{2}{*}{ Jumlah Item } & \multicolumn{4}{|c|}{ Hipotetik } & \multicolumn{5}{|c|}{ Empiris } & \multirow[b]{2}{*}{ Kategori } \\
\hline & & & 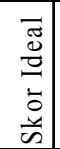 & $\begin{array}{l}\equiv \\
\vdots \\
\frac{0}{\omega}\end{array}$ & 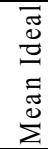 & 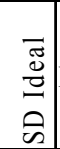 & MAX & MIN & MEAN & $\%$ & SD & \\
\hline 1 & Menyakiti orang lain secara fisik & 20 & 100 & 20 & 56 & 11,3 & 90 & 22 & 56 & 56 & 17 & Sedang \\
\hline 2 & Menyakiti orang lain secara verbal & 11 & 55 & 11 & 32 & 6,6 & 52 & 12 & 31,6 & 57,5 & 9,6 & Sedang \\
\hline & KESELURUHAN & 31 & 155 & 31 & 88 & 16,6 & 138 & 38 & 87,4 & 56,4 & 25,12 & Sedang \\
\hline
\end{tabular}

Tabel Agresivitas Siswa SMA Pertiwi 2 Padang (Siltami Elga Omala. 2018).

Tabel 1 mengungkapkan bahwa secara keseluruhan skor tingkat agresivitas rata-rata 87,4 yang berada pada kategori sedang $(56,4 \%)$. Selanjutnya pada aspek menyakiti orang lain secara fisik ratarata skor 56 yang berada pada kategori sedang (56\%), dan pada aspek menyakiti orang lain secara verbal rata-rata skor 31,6 yang juga berada pada kategori sedang $(57,5 \%)$. Untuk lebih lanjut, deskripsi tingkat agresivitas secara keseluruhan dapat dilihat pada tabel 2.

\section{Empati SMA Pertiwi 2 Padang}

Temuan penelitian empati dapat dilihat pada gambarannya sebagai berikut.

Tabel 2. Empati Siswa SMA Pertiwi 2 Padang

\begin{tabular}{|c|c|c|c|c|c|c|c|c|c|c|c|c|}
\hline \multirow[b]{2}{*}{ No } & \multirow[b]{2}{*}{ Aspek } & \multirow[b]{2}{*}{ Jumlah Item } & \multicolumn{4}{|c|}{ Hipotetik } & \multicolumn{5}{|c|}{ Empiris } & \multirow[b]{2}{*}{ Kategori } \\
\hline & & & 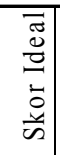 & 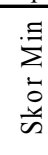 & 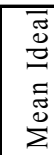 & 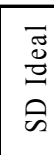 & & MIN & MEAN & $\%$ & $\mathrm{SD}$ & \\
\hline 1 & Perspective taking & 9 & 45 & 9 & 30 & 4,6 & 44 & 16 & 30 & 66,7 & 7 & Tinggi \\
\hline 2 & Fantasi & 5 & 25 & 5 & 13 & 2,3 & 20 & 6 & 13,5 & 54 & 3,6 & Sedang \\
\hline 3 & Empaticoncern & 9 & 45 & 9 & 30,5 & 4,8 & 45 & 16 & 32,7 & 72,7 & 7 & Tinggi \\
\hline 4 & Personal distres & 5 & 25 & 5 & 17 & 2,6 & 25 & 9 & 17,3 & 69,2 & 4 & Tinggi \\
\hline & KESELURUHAN & 28 & 140 & 28 & 96 & 13 & 135 & 57 & 97 & 69,3 & 21,63 & Tinggi \\
\hline
\end{tabular}

Tabel Empati Siswa SMA Pertiwi 2 Padang (Siltami Elga Omala. 2018).

Tabel 2 mengungkapkan bahwa secara keseluruhan tingkat empati siswa rata-rata 97 yang berada pada kategori tinggi $(69,3 \%)$. Selanjutnya pada aspek perspective taking rata-rata skor 30 yang yang berada pada kategori tinggi $(66,7 \%)$, Pada aspek fantasi rata-rata skor 30 berada pada kategori sedang (54\%), pada aspek empati concern rata-rata skor yaitu 32,7 berada pada kategori tinggi $(72,67 \%)$ dan 
pada aspek personal distress rata-rata skor yaitu 17,3 yang berada pada kategori tinggi (69,2\%). Untuk lebih lanjut, deskripsi tingkat empati secara keseluruhan dapat dilihat pada tabel 4.

3. Hubungan Empati dengan Agresivitas Siswa

Temuan penelitian hubungan empati dengan agresivitas siswa dapat dilihat gambarannya sebagai berikut.

Tabel . Korelasi Empati (X) dengan Agresivitas (Y)

\begin{tabular}{|c|c|c|c|}
\hline \multicolumn{2}{|c|}{ Correlations } & EMPATI & AGRESIVITAS \\
\hline \multirow{3}{*}{ EMPATI } & Pearson Correlation & 1 &,$- 695^{* *}$ \\
\hline & Sig. (2-tailed) & & ,000 \\
\hline & $\mathrm{N}$ & 152 & 152 \\
\hline \multirow{3}{*}{ AGRESIVITAS } & Pearson Correlation &,$- 695^{\star *}$ & 1 \\
\hline & Sig. (2-tailed) & ,000 & \\
\hline & $\mathrm{N}$ & 152 & 152 \\
\hline
\end{tabular}

Tabel Hubungan Empati dengan Agresivitas Siswa (Siltami Elga Omala, 2018

Berdasarkan hasil pengolahan dengan menggunakan program SPSS for windows 20, dapat dikemukakan bahwa terdapat hubungan negatif yang signifikan antara empati dengan agresivitas siswa SMA Pertiwi 2 Padang,

\section{Pembahasan}

\section{Agresivitas SMA Pertiwi 2 Padang}

Berdasarkan hasil penelitian tingkat agresivitas siswa SMA Pertiwi 2 Padang berada pada kategori cukup tinggi. Dengan demikian dapat dipahami bahwa tingkat agresivitas siswa relatif sedang yang artinya sebagian siswa melakukan tindakan agresivitas. Menurut Atkinson, Atkinson, dan Hilgard (2008:58) aspek-aspek dalam prilaku agresif yang timbul pada individu yaitu aspek fisik dan aspek verbal berikut uraian masing-masing aspek

Berdasarkan hasil analisis data yang dilakukan diperoleh hasil bahwa siswa yang menyakiti orang lain secara fisik memiliki skor rata-rata 56 , dengan persentase $56 \%$ berada pada kategori sedang. Sejalan dengan itu Bush \& Perry (dalam Mimi Ariyanti Eka S, 2012:12) salah satu bentuk perilaku agresif adalah phsycal Agression, yaitu perilaku agresif dengan menggunakan kekuatan fisik ketika mengungkapkan kemarahan atau agresifnya contohnya memukul. Agresifitas yang terjadi pada siswa, didominasi oleh emosi negatif. Oleh sebab itu, siswa perlu mengontrol diri agar dapat mengelola emosi negatif yang tidak terkendali seperti merugikan orang lain secara fisik.

Pada aspek menyakiti secara verbal memiliki skor rata-rata 31,6 dengan persentase $57,45 \%$ berada pada kategori sedang. Remaja yang melakukan tindakan agresif yang menyakiti orang secara verbal lebih sering dalam keadaan tertekan, dalam keadaan berkelahi pun remaja mengeluarkan kata-kata kasar untuk menyakiti orang lain. Hal ini sesuai dengan pendapat Bush \& Perry (dalam Mimi Ariyanti Eka, S, 2012:12) salah satu bentuk perilaku agresif adalah verbal agression yaitu perilaku agresif dengan cara verbal argumentatif. Contohnya berkata kotor, memaki dan menyela.

Menurut Fiman (2016) kontrol diri merupakan kemampuan individu mengontrol dan mengelola perilaku sesuai dengan kondisi untuk menampilkan diri dalam melakukan sosialisasi kemampuan untuk mengendalikan perilaku, kecenderungan menarik perhatian, keinginan mengatur perilaku agar sesuai dengan orang lain, menyenangkan orang lain, konform dengan orang lain dan menutupi perasaan yang sedang dialami. Oleh sebab itu, siswa perlu memahami perasaan orang lain dan mengontrol diri agar dapat mengelola emosi negatif yang tidak terkendali seperti berkata kasar.

\section{Empati}

Berdasarkan hasil penelitian tingkat empati siswa SMA Pertiwi 2 Padang berada pada kategori tinggi. Dengan demikian dapat dikemukakan bahwa secara umum empati siswa relatif tinggi. Hal ini 
berarti kebanyakan siswa SMA Pertiwi 2 Padang memiliki kemampuan empati yang baik. Berikut uraian masing-masing aspek.

Pada aspek Perspective taking diperoleh hasil bahwa skor rata-rata 30 dengan persentase $66,7 \%$ berada pada kategori tinggi. Menurut Davis (dalam Anayanti Rahmawanti, 2014) Perspective taking merupakan kecenderungan seseorang untuk mengambil sudut pandang orang lain secara spontan. seseorang dapat menyimpulakan kondisi orang lain, memahami dari perspective mereka, dan dapat pula menginterpretasikan serta memprediksi perilaku selanjutnya. Kunci pokoknya yaitu dimana seseorang dapat mengoptimalkan kemampuan berpikirnya dan memahami kondisi orang lain. Aspek ini berhubungan dengan membina hubungan sosial yang baik sehingga dengan demikian siswa perlu mempertahankan dan mengembangkan kemampuan perspective taking agar memiliki empati yang baik.

Pada aspek fantasi diperoleh hasil bahwa skor rata-rata 13,5 dengan persentase $54 \%$ berada pada kategori sedang. Sejalan dengan itu Menurut Davis (dalam Anayanti Rahmawanti, 2014) Fantasi merupakan kemampuan seseorang untuk mengubah diri mereka secara imajinatif dalam mengalami perasaan dan tindakan dari karakter khayal dalam buku, film, sandiwara yang dibaca atau ditontonnya. Oleh sebab itu, siswa perlu meningkatkan aspek fantasi agar dapat menempatkan diri secara imajinatif.

Pada aspek emphati concern diperoleh hasil bahwa skor rata-rata 32,7 dengan persentase $72,2 \%$ berada pada kategori tinggi Menurut Davis (dalam Nashori, 2008) empati concern merupakan orientasi seseorang terhadap orang lain berupa perasaan simpati, kasihan dan peduli terhadap orang lain yang ditimpa kemalangan. Seseorang yang mempunyai empati concern yang tinggi maka lebih peka dan memiliki kepedulian kepada orang lain. Oleh sebab itu siswa perlu mengembangkan dan mempertahankan aspek empati concern yang dimiliki.

Pada aspek personal distress diperoleh hasil bahwa skor rata-rata 17,3 dengan persentase $69,2 \%$ berada pada kategori tinggi. Aspek personal distress merupakan kecemasan pribadi yang berorientasi pada diri sendiri serta kegelisahan dalam menghadapi setting interpersonal yang tidak menyenangkan (Rahmawati, 2014). Kegelisahan dalam hubungan interpersonal menyebabkan individu melarikan diri dari situasi tersebut untuk mereduksi ketegangan, sehingga seseorang dengan personal distress yang tinggi akan memiliki empati yang rendah Oleh sebab itu agar siswa memiliki empati yang tinggi maka siswa perlu mengurangi personal distress.

\section{Hubungan Empati dengan Agresivitas}

Selanjutnya penelitian ini dilakukan untuk mengetahui ada tidaknya hubungan antara empati dengan agresivitas siswa SMA Pertiwi 2 Padang. dengan koefisien sebesar -0,695 dan taraf signifikansi 0,000 . Hubungan yang signifikan negatif ini dapat diartikan, semakin tinggi empati maka tingkat agresivitas semakin rendah. Sebaliknya, semakin rendah empati maka tingkat agresivitas semakin tinggi.

Menurut Decety dan Jackson (dikutip dari Andreasson, 2010) empati secara alami merupakan pengalaman subjektif yang memiliki kesamaan antara perasaan yang diekspresikan oleh diri sendiri dan orang lain tanpa mengabaikan perasaan yang lainnya. Empati tidak hanya melibatkan pengalaman efektif keadaan emosi atau penafsiran orang lain, tetapi juga sedikit pemikiran dalam memahami kondisi emosional orang lain.

Hasil penelitian yang dilakukan oleh Paul A. Miller dan Nancy Eisenberg (1988) yang berjudul "The Realtion of Empathy to Aggressive and Externalizing/Antisocial Behavior" dari hasil penelitian ini diperoleh kesimpulan bahwa empati memiliki hubungan negatif dengan agresi.

Hal yang serupa juga dinyatakan oleh Jianghe Niu (2009) salah satu faktor internal yang terkait dengan agresi adalah faktor emosi. Adapun pada faktor emosi terdapat beberapa aspek yaitu marah, iri/cemburu, dan empati. Namun marah, iri/cemburu berhubungan positif terhadap perilaku agresif, sedangkan empati berhubungan negatif terhadap tindakan agresif.

Sebagaimana yang dikemukakan oleh E. Koeswara (1988) Cara konkret yang dapat digunakan untuk mencegah berkembangnya tingkah laku agresif yaitu penanaman moral, pengembangan tingkah laku non agresif, pengembangan kemampuan memberikan empati. Dan salah satu cara untuk mengurangi agresivitas adalah pengembangan kemampuan empati yaitu Kemampuan memberikan empati merupakan cara yang perlu diambil dalam usaha mencegah berkembangnya tingkah laku agresif. Kemampuan seperti itu dapat berkembang dengan baik bila individu dilatih dan melatih diri untuk mampu menempatkan diri pada dunia batin sesamanya, mampu merasakan dan yang dialami atau yang diinginkan sesamanya. Cara ini pun perlu menjadi tanggung jawab bersama, bahkan segenap orang yang menginginkan terciptanya keamanan, ketertiban dan ketentraman. 


\section{Kesimpulan dan Saran}

Berdasarkan hasil analisis data yang telah dibahas pada bab terdahulu tentang hubungan empati dengan agresivitas pada siswa, maka dapat disimpulkan bahwa: (1) tingkat agresivitas siswa berada pada kategori sedang, (2) tingkat empati siswa berada pada kategori tinggi, (3) Terdapat hubungan negatif yang signifikan antara empati dengan agresivitas siswa. Artinya, siswa yang memiliki tingkat empati tinggi akan memiliki agresivitas rendah, begitu jika sebaliknya, jika empati siswa rendah maka agresivitas tinggi.

\section{Daftar Rujukan}

Atkinson, R. L., Atkinson, R. C. \& Hilgard, E. R.. (2008). Pengantar psikologi/ Edisi Kedelapan/ Jilid II. Alih Bahasa Oleh Nudjannah Taufik. Jakarta: Erlangga.

Baron \& Byrne. (2005). Psikologi sosial. Alih bahasa: Ratna Djuwita. Jakarta: Erlangga.

David G, Myers. (2012) Psikologi sosial (Edisi Sepuluh). Alih Bahasa oleh Aliya Tusyani. Jakarta: salemba humanika.

Firman, Karneli, Y., Hariko, R. (2016). Pencegahan Tindakan Kekerasan Melalui Pengembangan Panduan Pelaksanaan Layanan Informasi Menggunakan Pendekatan Problem Solving Dalam Peningkatan Kontrol Diri Siswa Sekolah Menengah Kejuruan (Smk) Kota Padang. Padang: FIP UNP

Ismiati. (2015). Hubungan Kematangan Emosi dengan Perilaku Agresif dan Implikasinya dalam Pelayanan BK. Skripsi Tidak diterbitkan. Padang: BK FIP UNP.

Koeswara. E. (1988). Agresi manusia. Bandung: Erasa.

Miller, PA \& Eisenberg, N. (1988). The Relation of Empathy to Aggressive and Externalizing/ Antisocial Behavior. Psychological Bulletin, 103 (3), 324.

Mimi Ariyanti Eka, S. 2012 Hubungan Antara Konsep Diri Dengan Agresifitas pada Siswa SMK 5 Padang. Skripsi tidak diterbitkan. Psikologi UNP

Nashori, F. (2008) Psikologi Sosial Islam. Bandung: Refika Aditama

Niu Jianghe. (2009). Internal factors related to relational aggression in childhood and adolescence. Educational Research and Reviews, 4(1), 001-008.

Novia Nadia Bestari. (2016). Hubungan interaksi sosial teman sebaya dengan agresivitas siswa serta implikasinya dalam bidang penegmbangan sosial. Skripsi Tidak diterbitkan. Padang: BK FIP UNP.

Panavia. (2012). Hubungan antara konsep diri dan agresivitas siswa. Skripsi Tidak diterbitkan. Padang: BK FIP UNP.

Prayitno, Elida. (2006). Psikologi perkembangan remaja. Padang: Angkasa Raya.

Rahmawati, Anayanti. (2014). "Metode Bermain Peran dan Alat Permainan Edukatif untuk Meningkatkan Empati Anak Usia Dini". Dalam Jurnal Pendidikan Anak. 3(1), 382-392

Randi Pratama. (2015). Prilaku Agresif Siswa Dari Keluarga Broken home. Skripsi Tidak diterbitkan. Padang: BK FIP UNP.

Santrock, J.W. (2007). Psikologi Perkembangan. Edisi 11 Jilid 1. Jakarta: Erlangga

Saputri, Mimi Ariyanti Eka. 2012 Hubungan Antara Konsep Diri Dengan Agresifitas pada Siswa SMK 5 Padang. Skripsi tidak diterbitkan. Psikologi UNP

Taufik. (2012). Empati pendekatan psikologi sosial. Jakarta: Erlangga. 